\title{
Espaços de Morte e Representações Sociais de Travestis na Cidade de Ponta Grossa - Paraná
}

\author{
Spaces of Death and Social Representations of Travesti in the City of Ponta \\ Grossa - Paraná
}

\author{
Vinicius Cabral \\ Grupo de Estudos Territoriais / UEPG \\ vinicius.cabral.1991@gmail.com

\section{Joseli Maria Silva} \\ Grupo de Estudos Territoriais / UEPG \\ joseli.genero@gmail.com \\ Marcio Jose Ornat \\ Grupo de Estudos Territoriais / UEPG \\ geogenero@gmail.com
}

\section{Resumo}

O objetivo desta discussão é compreender a relação entre espaço e morte nas representações sociais de travestis em Ponta Grossa - Paraná. Para tanto foram realizadas oito entrevistas com pessoas que se autoidentificaram como travestis, moradoras da cidade de Ponta Grossa. Para conduzir a entrevista foi utilizado um roteiro semi-estruturado de questões relativas às suas experiências de ameaça, risco de morte de si mesmas e de outras travestis. O trabalho evidenciou que as espacialidades vinculadas ao risco de morte são o território da prostituição travesti, a cidade, a casa, os hospitais, as delegacias, as boates, os velórios, e a vizinhança. O trabalho revela que o espaço geográfico é uma dimensão da sociedade, em que o padrão hegemônico é a heteronormatividade. Desta forma, todos os que não se enquadram na heteronormatividade, acabam sofrendo severas punições, através do espaço geográfico.

Palavras-chave: Travesti, Morte, Espaço Urbano.

\begin{abstract}
The aim of this discussion is understand the relationship between space and death on the social representations of travestis in Ponta Grossa - Paraná. Therefore, we carried out eight interviews with people who self-identified as travestis, residents of the city of Ponta Grossa.To conduct the interview was using a semi-structured questions relating to their experiences of threat, risk of death from themselves and other travestis. The work showed that spatialities related to the risk of death are the Territory of transvestite prostitution, the city, home, the hospitals, police stations, the nightclubs, the funerals, and the neighborhood. The study reveals that the geographical space is a dimension of society, in which the standard is hegemonic heteronormativity in this way all who do not fit the heteronormativity, suffer severe punishments, through the geographic space.
\end{abstract}

Keywords: Travesti, Death, Urban Space. 


\section{Introdução}

A presente discussão evidencia a relação entre espaço e morte, através das representações sociais de travestis moradoras da cidade de Ponta Ponta Grossa Paraná. Esta busca de produção de inteligibilidade relacionada a este fenômeno nasceu de vários caminhos de pesquisa construídos pelo Grupo de Estudos Territoriais (GETE), em que fora detectada a constante presença do risco de morte e à vulnerabilidade do grupo aos atos de violência. Os trabalhos de Silva (2009) sobre os espaços interditos à vivência travesti e de Ornat (2008) que investigou a prática da prostituição, apontavam para experiências sociais repletas de violência e exclusão que tornavam o risco de morte um elemento constante da vivência travesti. Os relatos de companheiras mortas e de sua sensação de uma morte prematura levaram ao estabelecimento desta discussão.

Operacionalizando a construção desta investigação, busquemos compreender quais eram os elementos constituidores das representações travestis em torno do risco de morte, como a morte estava representada nos relatos das experiências travestis e como a relação entre espaço e morte estruturava as representações sociais das travestis em Ponta Grossa - Paraná.

Assim, para responder às questões estabelecidas, foram realizadas oito entrevistas com o grupo de travestis, moradoras da cidade e Ponta Grossa Paraná, e que atuam na atividade da prostituição, de forma ativa ou casual. Para a realização destas entrevistas foi utilizado um roteiro semi-estruturado (em anexo) com o grupo focal. O volume de falas produzidas a partir do processo de entrevista teve seu conteúdo analisado segundo a constituição de redes semânticas, assim como proposto por Bardin (1977), que davam sentido as dimensões espaciais, discursos que foram construídos sobre as espacialidades e que nasceram das vivências espaciais.

A partir de frequências e análises de categorias de discurso, evidenciamos as várias espacialidades que compõem a vivência travesti ao longo de suas vidas. Esta análise do conteúdo das falas de todas as pessoas entrevistadas esteve assentada, como proposto pelo autor, no agrupamento das evocações e na quantificação das frequências e dos agrupamentos destas evocações.

Portanto, desenvolvemos esta reflexão a partir de duas seções. A primeira seção intitulada 'Espaço e Morte de Travestis e as suas Representações Sociais' versa sobre os eixos teóricos conceituais que nos ajudam a compreender a relação entre a vivência travesti e a morte. A segunda seção intitulada 'A Morte de Travestis e os Elementos Constituidores das
Representações Sociais de suas Espacialidades' apresenta, através das representações sociais das travestis que residem na cidade de Ponta Grossa Paraná, as espacialidades vinculadas ao risco de morte.

\section{Espaço, morte de travestis e as suas Representações Sociais}

A vivência espaço-temporal pode ser concebida e experienciada de forma contínua ou descontínua, com rupturas brutais ou bloqueios espaço-temporais, como argumenta Corrêa (1995) em sua discussão sobre o espaço como conceito-chave da Geografia. Segundo o autor, no processo de produção e organização do espaço, os grupos sociais criam um conjunto de ações, através das quais são possibilitadas a criação, a reprodução, a destruição e a reconstrução das formas e das interações espaciais. Estas ações, não estritamente relacionadas as materialidades, seriam resultado, de um lado, da aceitação pelos grupos sociais da própria existência da diferenciação espacial, e de outro, dos projetos orientados à viabilização da existência e à reprodução social, e nesta discussão, a partir da luta cotidiana pela sobrevivência, perpetrada pelo grupo específico das travestis.

A sociedade ocidental contemporânea tem como uma de suas características a linearidade estabelecida para os corpos entre sexo, gênero, prática sexual e desejo (BUTLER, 2003). A partir destes elementos lineados, os corpos e seus comportamentos demandam inteligibilidade a partir desta matriz ou ordem heterossexual. Neste caminho, todo corpo que não tem correspondência a esta característica linear, correspondência aos padrões estabelecidos de normalidade ou não normalidade heterossexual, é nomeado como desviante a partir dos mais variados qualificativos, produzindo o efeito da reprodução da normalidade e a manutenção de sua 'ordem natural'.

O grupo que nos têm instigado é aquele justamente que tensiona esta ordem linear, questionando a ligação padrão heterossexual entre sexo, gênero, prática sexual e desejo, referindo-se às travestis. A vivência deste grupo específico corrobora às afirmações de Butler (2003), a partir de sua desconstrução desta pretensa naturalidade, argumentando esta autora que há uma construção cultural que classifica os corpos a partir de suas características físicas de macho ou fêmea, instituindo a ordem poderosa da heteronormatividade.

A partir da consideração realizada por Butler (2003) sobre a heteronormatividade, as espacialidades ocidentais estruturam-se no que Valentine (1993) denomina como 'espaço heterossexual', ou seja, constrangendo as ações dos sujeitos em direção a esta configuração de práticas de gênero e sexualidade.

Vinicius Cabral, J oseli Maria Silva e Marcio Jose Ornat 
Como apontado pela autora, a heterossexualidade é uma prática sócio-sexual dominante na cultura ocidental moderna, não definida apenas pelos atos sexuais nas espacialidades privadas, mas estabelecida a partir de relações de poder que se operam em todas as espacialidades cotidianas, espacialidades heterossexuais que se colocam enquanto invisíveis, até que suas fronteiras sejam transgredidas. Evidenciamos que esta transgressão de fronteiras relaciona-se à vivência espacial, nas mais variadas possibilidades existenciais do grupo de travestis ao longo de suas vidas.

Parafraseando a proposta de Louro (2004), os corpos travestis carregam marcas. Em seu diálogo com Butler $^{1}$ os discursos sobre as marcas dos corpos habitam os corpos, acomodam-se nos corpos, compõe os corpos como parte de seu sangue. E neste sentido, como tratado por Louro, pouco importa saber quem iniciou estas marcações e quais eram ou são as suas intenções. O que importa é a produção de inteligibilidade em relação a estes processos e seus efeitos, pois segundo as palavras da autora:

o que importa é que ela terá, além de efeitos simbólicos, expressão social e material. Ela poderá permitir que o sujeito seja reconhecido como pertencente a determinada identidade; que seja incluído em ou excluído de determinados espaços (...); que possa (ou não) usufruir de direitos; (...) que seja, em síntese, aprovado, tolerado ou rejeitado (LOURO, 2004, p. 83 - 84)

Como visto a partir das falas das travestis, esta rejeição, resultado dos discursos relacionados aos corpos das travestis, são estruturadas a partir da violência, que diversas vezes culmina na morte. Neste caminho, a violência contra homossexuais é um tema explorado por Namaster (2000), a qual apontando que lésbicas e gays são atacados de forma diferente, de acordo com o espaço publico e suas ocupações sociais. A autora chama a atenção para a demanda de problematização da violência direcionada a outros grupos, ou como nos termos da autora, em relação ao grupo de trangêneros ${ }^{2}$, problematizando assim a estreita entre suas identidades de gênero e a violência sofrida. Corroborando ao proposto por Namaster (2000), a argumentação de Silva (2009) aponta que as travestis compõem o grupo mais vulnerável à violências:

Queremos chamar atenção para o fato de que as travestis sofrem maior violência e preconceito porque a marca da transgressão é nítida, visual e, portanto, afronta o poder heteronormativo, muito menos evidente no gay ou na lésbica. (SILVA, 2009, p. 142)

Este poder heteronormativo está inscrito no espaço urbano. Entretanto, as travestis subvertem este poder, com isto sofrendo uma série de constrangimentos e violências ao longo de sua construção identitária de gênero, como podemos observar em Silva (2009). A mesma autora aponta que os principais espaços interditos são as escolas, os hospitais, os clubes, as danceterias, os restaurantes, as penitenciárias, as delegacias de polícia, o exército e as igrejas. Há casos em que as interdições geram não só a privação, mas também a violência e a morte.

A Organização Mundial da Saúde - OMS (2002) define a violência como sendo qualquer força física ou poder simbólico, contra si mesmo ou grupo que culmine, ou tenha alta probabilidade de lesão, morte, dano psicológico ou privação. A mesma define a violência sobre quatro formas: a violência física que corresponde a toda manifestação com o objetivo de ferir; a violência psicológica, caracterizada pela humilhação, desrespeito, rejeição, entre outros; a violência sexual, quando o agressor abusa de seu poder sobre a vítima na obtenção da gratificação sexual, sem o consentimento da vítima; e a negligência, que é a omissão do responsável em proporcionar as necessidades básicas de seu dependente. Todas estas quatro formas de violência caracterizadas pela OMS fazem parte do cotidiano espacial das travestis.

Além da violência que permeia a vivência travesti, a morte também permeia o sentimento espacial das travestis, através de sentimentos fóbicos, de experiências de morte de amigas e também de vulnerabilidades. Esta realidade subverte a lógica do pensamento sobre a morte, como podemos visualizar em Ariés (1975, p.168). Como tratado pelo autor, "nos últimos trinta anos produziu-se um fenômeno imenso de que mal nos começamos a perceber: a morte, essa companheira familiar, desapareceu da linguagem e o seu nome tornou-se interdito". Este cenário exposto aqui por Ariés não é uma realidade das travestis, pois estas expõe seus corpos aos riscos de morte, e a mesma não é interdita, pois elas possuem a morte enquanto um dos elementos centrais de suas vidas.

A realidade vivida pelo grupo de travestis é atravessada por vivências espaciais, materiais ou imateriais. Produzindo inteligibilidade aos fenômenos, a partir da proposição de Souza (1997), suas vidas vão além da antinomia objetividade versus subjetividade. Parafraseando o mesmo autor em sua publicação de 2002, compreendemos que a vivência espacial travesti é uma complexa mistura tanto de determinações

Vinicius Cabral, J oseli Maria Silva e Marcio J ose Ornat 
quanto de indeterminações. Suas vidas são compostas por regras e contingências, condicionamentos estruturais, ao lado de ranges de liberdades individuais, pois assim como proposto por Massey (2008) e Valentine (1993), o espaço vai além da totalizante perspectiva proposta de ser pensado apenas a partir da estrita materialidade.

A argumentação de Souza (1997) é de grande contribuição pois propõe que a dimensão material do espaço social, formulada pelos autores marxistas, é um ponto de partida válido. Todavia, segundo o autor, não é um ponto de chegada de uma conceituação exigente. Neste sentido, o autor argumenta que o espaço não é uma instância apenas objetiva, pois o espaço em sua objetividade é constituído pela intersubjetividade, ou seja, sua materialidade é repleta de significações exclusivas de cada indivíduo. Por outro lado, quando esta subjetividade é compartilhada por vários indivíduos, ela torna-se intersubjetiva. O processo de pesquisa evidenciou que a intersubjetividade produzida pelo grupo de travestis é constituída, entre outras coisas, por várias experiências de morte, estruturadas pelas representações sociais que o grupo tem sobre a relação entre espacialidade e morte.

As Representações Sociais (RS) podem ser compreendidas, através do diálogo de Silva (2002) com Moscovici ${ }^{3}$ (1978), entendendo assim que as RS são uma modalidade do conhecimento particular e que tem por função a criação de comportamentos e a comunicação entre os indivíduos. Ou seja, o cotidiano do sujeito o possibilita refletir sobre os fatos cotidianos, através de seus valores, informações, experiências, e fontes. Estas explicações são as representações sociais.

Em suma, as RS podem ser definidas, conforme demonstra Silva (2002, p. 192): "O ato de representar é uma reconstrução e não uma repetição ou reprodução, pois neste processo a realidade desconexa, ao ser reconstruída, faz circular e reunir experiências dos indivíduos, tornando o que é estranho em algo familiar para, assim, naturalizá-lo". Ao longo da transformação da travesti, ela questiona e ressignifica muitos dos elementos que compõem sua vida, como as relações familiares, a interdição que advêm das espacialidades heterossexuais (VALENTINE, 1993), a vulnerabilidade à morte, entre outros acontecimentos da vida cotidiana. Estes elementos são comunicados entre elas, criando assim as Representações Sociais.

As representações sociais de travestis em relação à morte são um dos textos que compõem a intertextualidade da cidade. A intertextualidade é observada nas ideias de Duncan (1990) pois este defende que os diferentes grupos possuem várias leituras/discurso sobre a cidade. Estes discursos podem ser conflitantes, harmoniosos ou complementares, sendo que esta visualização também refere-se a vivência cotidiana travesti, frente à outros grupos. Estas experienciam a cidade de uma forma diferente dos outros grupos, sendo que é neste sentido que a experiência espacial também é associada ao preconceito, a violência e com a sua possível consequência, a morte.

Ao analisarmos o fenômeno da interdição espacial, através das ideias de Silva (2009) podemos observar que ele é produzido cotidianamente pela sociedade heteronormativa, através de inúmeras espacialidades como hospitais, igrejas, escolas, clubes, penitenciárias, delegacias de polícia, entre outras. Contudo, a escola para a autora, além de ser uma das espacialidades interditas mais representativas da vivência travesti, é também responsável na contribuição da marginalidade social que as travestis quando adultas irão viver. A autora ainda argumenta que a escola enquanto espaço de solidariedade, igualdade, saber e inclusão é negada nas versões do grupo de travestis, pois como nas palavras da autora (p. 149) "a escola produziu dor, desrespeito e colaborou decisivamente para produção de representações sociais negativas que apenas reforçam a violência e hostilidade que as envolvem".

A prostituição travesti, aparece como um elemento resultante de todo o processo de exclusão na vida das travestis, pois em muitos casos, esta é a única possibilidade em que a travesti tem como fonte de renda/ocupação. Neste sentido, utilizaremos as ideias de Ornat (2008) na compreensão do histórico e de como a prostituição travesti esta estruturada na cidade de Ponta Grossa.

Para este autor, a história da prostituição na cidade de Ponta Grossa remonta desde a metade do Século $\mathrm{XX}$, período este em que as práticas da prostituição ocorriam relacionadas a mulheres profissionais do sexo. Mas a partir da década de 70 houveram as primeiras travestis na cidade, que começaram a atividade da prostituição travesti. $\mathrm{O}$ autor ressalta que as duas formas de prostituição ainda se mantem na cidade, cada uma com suas especificidades. Esta discussão aponta que o atual território travesti foi devidamente escolhido por suas características especificas, relacionadas a áreas com "pouca circulação de carros familiares nos horários em que as travestis estão batalhando, vias com acentuada passagem de pessoas que cruzam a cidade, ou pela cidade, e área em sua maioria comercial" (ORNAT, 2008, p.35). Embora a vida da travesti seja marcada pela exclusão/interdição, as travestis através das pequenas possibilidades desenvolvem suas próprias táticas de sobrevivência frente a diversidade de ameças, desde assaltos, brigas, rivalidades, violências,

Vinicius Cabral, J oseli Maria Silva e Marcio J ose Ornat 
drogas e discriminação.

As representações sociais são o processo de tornar o não familiar em familiar através da comunicação. Portanto, quando uma travesti é assassinada, as demais sabem e resinificam tanto o espaço em que ela foi assassinada, como suas próprias vidas. Esta violência é consequência do fato de que o espaço possuí uma 'sexualidade' inscrita, tornando-se assim em espaços heterossexuais. Desta forma, os diversos grupos que não se enquadram na heterossexualidade compulsória acabam que por sofrer diversos constrangimentos, violências e até mesmo a morte, como é o caso do grupo de travestis.

\section{A morte de travestis e os elementos constituidores das Representações Sociais de suas espacialidades}

Como visto anteriormente, Duncan (1990) ao trabalhar com a cidade de Kandy no Sri Lanka, aponta que os diversos grupos possuem diversos discursos (leituras) acerca da cidade, e que estes discursos podem ser conflitantes, harmoniosos ou complementares. Neste sentido, a vivência espacial dos sujeitos da cidade de Ponta Grossa, também acaba que por produzir discursos. Um destes grupos é o das travestis. Inicialmente, a tabela 1 apresenta o perfil do grupo entrevistado 4 .

\begin{tabular}{|c|c|c|c|c|c|}
\hline Nome & Idade & $\begin{array}{c}\text { Identidade de } \\
\text { Gênero }\end{array}$ & $\begin{array}{l}\text { Atua em } \\
\text { ONG? }\end{array}$ & Ocupaçōes & $\begin{array}{c}\text { A prostituição } \\
\text { é a principal } \\
\text { fonte de } \\
\text { renda? }\end{array}$ \\
\hline Lirio & 20 & Travesti & Nāo & $\begin{array}{l}\text { Profissional do } \\
\text { sexo }\end{array}$ & Sim \\
\hline Jasmim & 26 & Transexual & Nāo & $\begin{array}{l}\text { Profissional do } \\
\text { sexo }\end{array}$ & Sim \\
\hline Violeta & 28 & Travesti & Nāo & $\begin{array}{l}\text { Profissional do } \\
\text { sexo }\end{array}$ & Sim \\
\hline Azaleia & 34 & Travesti & Sim & $\begin{array}{c}\text { Profissional do } \\
\text { sexo, } \\
\text { cabeleireira, } \\
\text { Manicure e } \\
\text { Designer de } \\
\text { Sobrancelhas }\end{array}$ & Sim \\
\hline Iris & 40 & Travesti & Sim & $\begin{array}{l}\text { Profissional do } \\
\text { sexo, } \\
\text { Cabeleireira e } \\
\text { Costureira }\end{array}$ & Sim \\
\hline Tulipa & 42 & Transexual & Sim & $\begin{array}{c}\text { Profissional do } \\
\text { sexo, } \\
\text { Cabeleireira e } \\
\text { Massagista }\end{array}$ & Nāo \\
\hline Margarida & 48 & Travesti & Sim & $\begin{array}{c}\text { Profissional do } \\
\text { sexo, } \\
\text { Cabeleireira, } \\
\text { Manicure e } \\
\text { aposentada }\end{array}$ & Nāo \\
\hline Rosa & 52 & Transexual & Sim & $\begin{array}{l}\text { Profissional do } \\
\text { sexo casual e } \\
\text { aposentada }\end{array}$ & Nāo \\
\hline
\end{tabular}

Tabela 1 - Perfil do grupo entrevistado. 
O grupo das travestis na cidade de Ponta Grossa Paraná possuí um discurso sobre as espacialidades em que ocorrem interdições, práticas de violência, e morte. Os discursos ${ }^{6}$ que nasceram do processo de pesquisa foram analisados, a partir da proposta de Bardin (1977), segundo sua organização em redes semânticas, relacionadas as mais variadas espacialidades, a partir das 328 evocações que constituíam as oito entrevistas realizadas com o grupo. O gráfico 1 abaixo apresenta a configuração destas espacialidades, através das evocações, demonstrando assim quais espacialidades são mais significativas na relação entre interdição, violência e morte.

Para o desenvolvimento desta discussão, inicialmente tratamos sobre as espacialidades da Cidade, da Casa, do Hospital, Delegacia, Boate, Velório, Ongs, Vizinhança e Espacialidade Não Evidentes $^{7}$ para em seguida construir uma reflexão sobre a espacialidade do Território da Prostituição Travesti.

\section{As Espacialidades Representadas no Risco de Morte de Travesti}

O geógrafo James Duncan (1990) argumenta que a cidade pode ser representada de diferentes formas de acordo com a diversidade de grupos sociais e suas experiências. A vivência espacial das travestis produz um discurso específico sobre a cidade de Ponta Grossa que deve ser considerado. A cidade tem sido fruto de inúmeras abordagens ao longo da história do pensamento geográfico. Contudo, optamos em utilizar as ideias de Corrêa (2003, p. 9) em sua análise do espaço urbano, considerando-o "fragmentado e articulado, reflexo e condição social, um conjunto de símbolos e campos de lutas". Desta forma, o espaço urbano em sua 'fragmentação e articulação' se deve ao fato de que todas as suas espacialidades possuem conexões com as demais, através de vários tipos de fluxos, sendo eles de caráter material, como carros, pessoas, mercadorias, ou fluxos de caráter capitalista, como circulação de decisões e de investimentos de

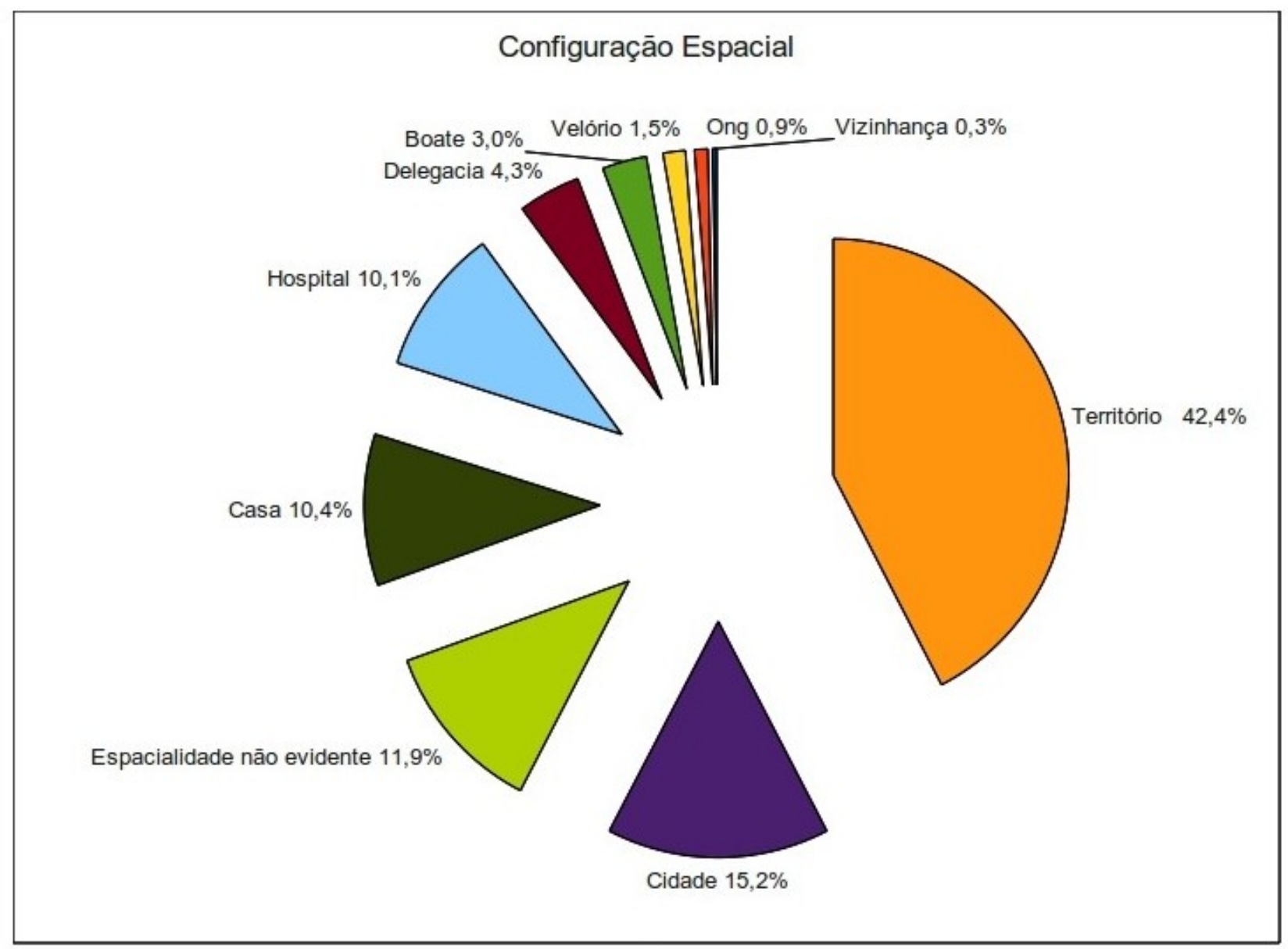

Gráfico 1 - Configuração Espacial das Evocações.

Vinicius Cabral, J oseli Maria Silva e Marcio J ose Ornat 
capitais.

Para Corrêa (2003) o centro da cidade é onde ocorre grande parte destas articulações. Neste sentido, o grupo das travestis é um dos que experienciam cotidianamente a fragmentação e articulação da cidade. Isto ocorre quando elas saem de suas residências e vão ao território da prostituição travesti, que está situado majoritariamente ${ }^{8}$ no centro da cidade ${ }^{9}$.

O espaço urbano como 'reflexo e condição' assume tal manifestação através deste ser o 'reflexo' da sociedade capitalista, em que há forte segregação espacial, reflexo das estruturas sociais do mundo capitalista. Neste sentido, Corrêa (2003, p. 8) ressalta que o espaço urbano é "reflexo tanto de ações que se realizam no presente, como também daquelas que se realizaram no passado e que deixaram suas marcas impressas nas formas espaciais do presente". Já o espaço urbano enquanto um 'condicionante' da sociedade relaciona-se ao fato de que a organização espacial desempenha papel na reprodução das relações sociais.
O espaço urbano para Corrêa (2003) ainda pode ser entendido enquanto 'um conjunto de símbolos' e 'campos de lutas'. O conjunto de símbolos está relacionado ao simbolismo que é diferente para cada grupo social, já o campo de lutas é tido pelo autor (p.9) como um "cenário e objeto das lutas sociais, pois estas visam, afinal de contas o direito à cidade, à cidadania plena e igual para todos".

Desta forma, a cidade enquanto um 'conjunto de símbolos' se relaciona a ideia de Duncan (1990) sobre as leituras/discursos de cada grupo social. Logo, a cidade é representada diferentemente para cada grupo social, como é o caso do grupo de travestis que fazem uma diferente leitura da cidade em relação aos demais grupos. Já a cidade enquanto um 'campo de lutas' é observada nos projetos orientados à viabilização da existência e à reprodução social, e nesta discussão, a partir da luta cotidiana pela sobrevivência. A leitura da cidade, para o grupo das travestis pode ser observada através do gráfico 2, que apresenta a configuração das evocações para a espacialidade da Cidade.

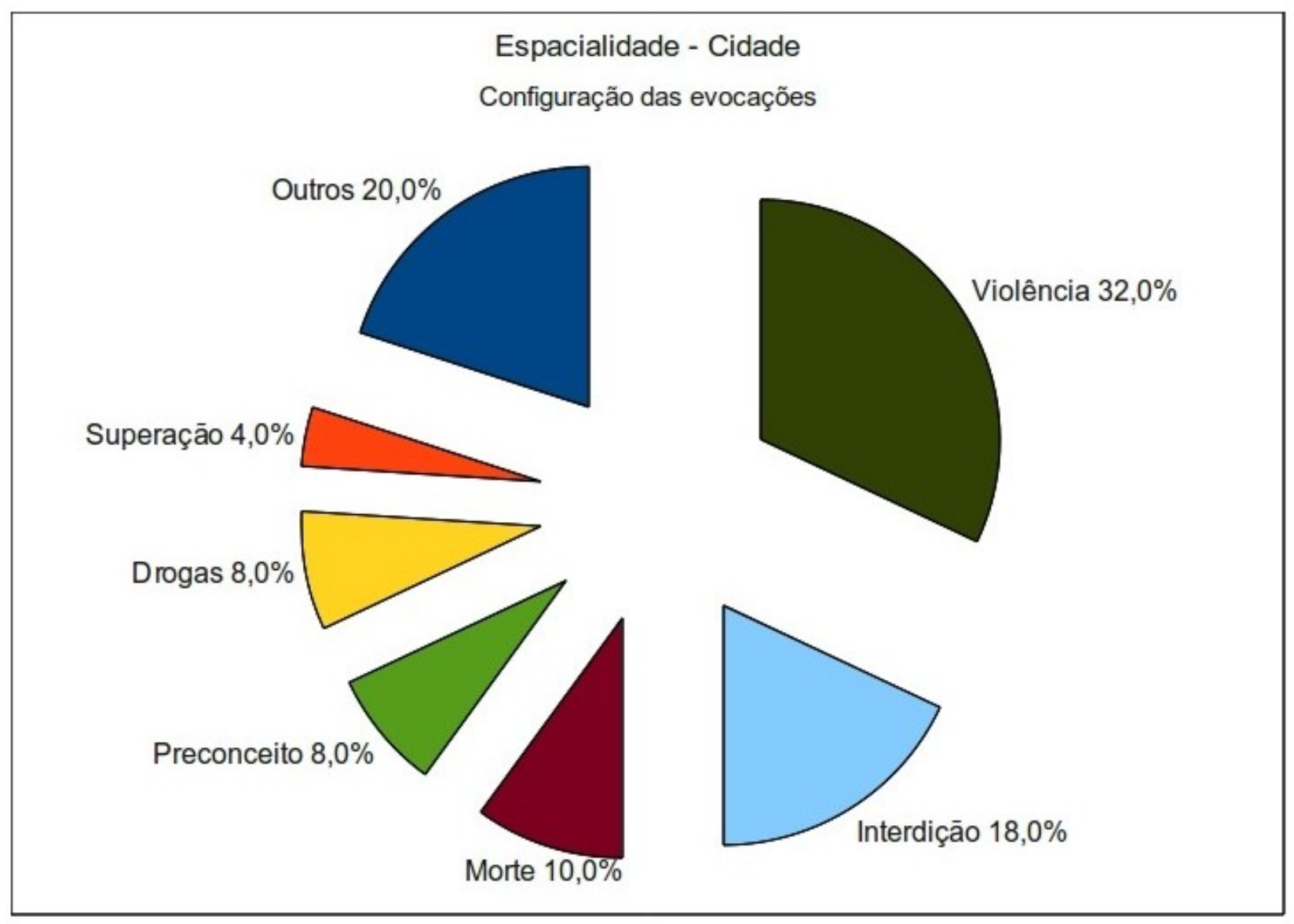

Gráfico 2 - Espacialidade - Cidade: Configuração das Evocações. 
As representações sociais das travestis sobre a cidade se constituem majoritariamente pela relação de violência, interdição e morte a que elas estão sujeitas. Em seguida evidencia-se o preconceito, o uso de drogas, e a superação enquanto representações sociais periféricas sobre a cidade. Assim, iremos explorar cada um destes elementos que compõem as representações sociais das travestis, nesta cidade.

A 'Violência' compõe o elemento de maior significância sobre a cidade com $32 \%$ do total de evocações. Esta violência está relacionada a alguns dos elementos que a OMS (2002) apresenta, como a violência física, psicológica, e sexual. Esta ponderação evidencia-se nas falas das travestis, relacionadas tanto a violência psicológica que todas as travestis sofrem, quanto a violência recebida por estar em um dos espaços de lazer que compõem a cidade.

porque o simples fato de você passar na rua e uma pessoa dizer "olha lá o viado sem vergonha, safado, olha lá a bicha, olha lá o traveco" cada dizer horrível que eles tem com a gente, não é só a violência, agressiva deles machucar você mas é também a violência no sentido moral de palavras, é muito dolorido, você chegar num lugar e ser agredida (Entrevista realizada com Margarida, em sua residência, no dia 6 de Agosto de 2011.)

eu não tava me prostituindo, eu tava trabalhando numa boate, né como cozinheira e daí todo o final de semana eu ia num clube, até não recordo o nome do clube, e daí la nessa noite me deu uma vontade, dai eu só bebi conhaque, conhaque, dai foi na vinda do clube que minhas amigas me abandonaram, eu vim sozinha pela $B R$, que era distante da boate, me pegaram em 5, (homens?) cinco homens, daí destes cinco homens eu tentei fugir, eu tive luta corporal com eles, até que não resisti e eles me levaram para um barracão abandonado, e todos tiveram relações sexuais comigo, o único que não teve foi um (...) que queria fazer o pior, colocar uma garrafa em mim daí nesta que tinha até um segurança do clube que eu tava, até o segurança se aproveitou, daí o segurança viu que ele queria colocar uma garra em mim, e disse assim não dá, assim não pode, agente só falou que ia fazer isto e ponto final, depois um deles viram que eu comecei a gritar pedir por socorro, eles me bateram, me bateram horrores, deixaram meu olho assim, inchado eu pensei que tinha perdido a minha lente verde, e tinha que fingir que tava morta, se não eles iam me matar (...) só me bateram, daí a única coisa que eles roubaram de mim foi um piercing do umbigo (arrancaram?) não, eles tiraram, tiveram o trabalho de tirar o piercing $e$ levar, só isto, mas não morri por Deus, depois daquela eu nunca mais sofri violência, depois me cuidei melhor hoje em dia eu não saio com dois, fico no truque de sair com um já, mas eu tomo bastante cuidado (Entrevista realizada com Azaleia, no Grupo Renascer, no dia 8 de Dezembro de 2011.)

A 'Interdição' aparece como outro elemento significativo com $18 \%$ do total de evocações sobre a cidade. A interdição aparece como a ausência de possibilidades associada ao desejo da morte das travestis. Estas práticas excludentes visam a reprodução da sociedade heteronormativa, através da cidade, como visto na evocação abaixo:

(como que a sociedade ia reagir ao saber da morte de uma travesti?) menos uma, acho que ia ser assim (risos), eu creio que sim, não dão oportunidade, privam de um monte de coisa e ainda querem (...) $e$ pagam as mesmas coisas que agente, e as vezes agente paga mais até porque pelo ganho da gente agente acaba gastando mais, só que o preconceito contra agente não adianta (Entrevista realizada com Violeta, em sua residência, no dia 30 de Maio de 2012.)

Outro elemento que compõe as representações sociais das travestis sobre a cidade é a 'Morte' com $10 \%$ do total de evocações. A representação social da morte, através da cidade, se dá pelo conhecimento de casos de pessoas que tem o anseio da morte de uma travesti, por crerem que elas são a escória da sociedade, e como elas não correspondem a lógica heterossexual inscrita na cidade, existe o desejo da morte delas:

a sociedade assim (...) eu falo assim que agente é culpa e a sociedade também, mas eu acho que tem as suas exceções, mas a maior parte dela, pega e da graças a Deus, porque elas pensam que agente é a escoria da sociedade, então pra elas tanto faz tanto

Vinicius Cabral, J oseli Maria Silva e Marcio J ose Ornat 
fez, quando morre uma é uma a menos ali, né que eu acho uma injustiça isto, né e os que fazem isto é porque não tem nem um caso na família porque a partir do momento que tiver um caso na família, eles vão ter outra visão, não é verdade? Porque quem tá de fora é fácil pegar e falar, criticar (Entrevista realizada com Iris, no Grupo Renascer, no dia 7 de Dezembro de 2011.)

O 'Preconceito' é outro elemento, que compões as representações sociais das travestis sobre a cidade. Ele aparece com $8 \%$ do total de evocações, estando relacionado as representações sociais dos sujeitos produtores desta violência psicológica. Este preconceito pode ser visto através da fala da entrevistada ao relatar que as representações sociais de outros grupos sobre a morte de uma travesti se relacionam exclusivamente a morte por doenças oportunistas, associadas ao vírus da AIDS, e não a outros elementos enquanto causa mortis:

geralmente quando eles sabem que uma travesti morre é que nem quando surgiu a AIDS é uma praga gay, ninguém quer saber, tem muitas que batem o carro, são tudo loca da cabeça, entra debaixo do caminhão, bate num poste, ninguém quer saber uma travesti morreu, esta praga morreu de AIDS, ninguém tem um pensamento bom e vejo, veja bem a AIDS, não não nem epidemia é uma pandemia que não tem controle e hoje em dia em pesquisas feitas é constatado, as travestis, os gays e as prostitutas tão fora dessa onda, aderiram ao uso do preservativo, aos tratamentos enfim se cuidar, hoje em dia o grupo de risco é o ser humano normal, os homem, os adolescentes, que toda semana eles tão trocando de parceira (Entrevista realizada com Margarida, em sua residência, no dia 6 de Agosto de 2011.)

O elemento 'Drogas' é outro elemento que compõe as representações sociais sobre a cidade, e corresponde a $8 \%$ do total de evocações. As drogas, se relacionam a uma mudança no comportamento dos vários grupos que vivenciam a cidade. Evidenciamos a fala da travesti Margarida sobre o crack:

depois que surgiu a droga chamado Crack, acabou o mundo, não só das travesti, mas das prostituta, dos garotos de programa, até pra sociedade o crack destruiu o mundo, acabou com o mundo, o crack tornou uma pandemia tão grande, não tem como a pessoa usou uma vez acabou, daí a pessoa fica sem vergonha ela rouba por cauda daquilo (Entrevista realizada com Margarida, em sua residência, no dia 6 de Agosto de 2011.)

A 'Superação' é um dos elementos que compõe as representações sociais das travestis, corresponde a $4 \%$ do total de evocações sobre a cidade. A superação se relaciona as conquistas do grupo na cidade, como tratado na fala da travesti abaixo:.

hoje em dia nos temos travestis aqui em Ponta Grossa, que tá na universidade, que tá no SECAL, ela tá estudando, ela não se prostitui ela estuda (...) (quem é que tá lá na SECAL?) é a (nome omitido $A^{10}$ ) que tá estudando no SECAL, é uma Loira muito bonita, quer dizer se prostituiu achou que não era o dela e o que que ela fez encarou o povão, a (nome omitido B) era na época, era eu acho que diretora de educação aqui (era) a (nome omitido B) foi apresentar ela na Universidade, olha ela vai ficar aqui, ela vai estudar, e vocês vão ter que estudar a (nome omitido B) era da secretaria municipal de educação, ela tá lá estudando, quer dizer nos temos travesti aqui, nos temos transexual aqui em Ponta Grossa que é professora, a (nome omitido C) que trabalhou com nós no Renascer, a (nome omitido C) é professora, hoje em dia aonde é que ela trabalha? Ela trabalha dentro da prefeitura, na ouvidora da prefeitura, quer dizer isto é uma conquista, aqui em Ponta Grossa nos temos poucas, mas em Curitiba, em Londrina, em São Paulo, no Rio de Janeiro, tem travesti advogada, tem travesti dentista, tem travestis em profissões que você não acredita, mas elas tão lá, mas a partir da hora que (...) se a 'raça' fosse unida, a gente era mais respeitada, só que a nossa própria raça, as próprias travestis não são unidas, então por isto que elas não conquistam as coisas (Entrevista realizada com Margarida, em sua residência, no dia 6 de Agosto de 2011.)

Por fim a categoria 'Outros' que representa $20 \%$ do total de evocações sobre a cidade apresenta um padrão discursivo disperso, não sendo possível construir um eixo semântico. Esta categoria se relaciona à

Vinicius Cabral, J oseli Maria Silva e Marcio J ose Ornat 
elementos como o acesso livre à cidade, a admiração que as pessoas sentem em relação às travestis, a família, a injustiça, transformação do corpo, reconhecimento e militância.

Afirmamos que o espaço urbano é fragmentado e articulado, reflexo e condição social, e um conjunto de símbolos e campos de lutas. Através destas possibilidades que o grupo das travestis constroe suas representações sociais a cerca da cidade. A cidade para o grupo das travestis é estruturada pelas seguintes representações hegemônicas, relacionadas a violência, a interdição e a morte, e pelas representações periféricas de preconceito, das drogas e da superação.

As representações sociais relacionadas a espacialidade dos hospitais orientam-se a partir de eixos semânticos que não trazem a morte física no hospital, mas sim um caminho que leva à morte pela interdição, a negação ao atendimento e ao tratamento das doenças ou de lesões fruto de agressões. O gráfico 3 apresenta a forma em que o hospital está estruturado a partir das representações sociais do grupo de travestis.

A 'Interdição' é um dos elementos que compõem as representações sociais das travestis em torno dos hospitais, correspondendo a $60,6 \%$ do total de evocações relacionadas a esta espacialidade. A interdição ocorre quando a equipe médica ou de enfermagem trata mal as travestis. Este é um dos elementos que causa medo nas travestis, e consequentemente elas não retornam ao hospital. A interdição é fruto das espacialidades heterossexuais (VALENTINE, 1993) que são hegemônicas no campo da saúde. Podemos observar a interdição sendo manifestada nestas espacialidades da saúde, através das duas falas das entrevistadas abaixo:

a falecida (nome omitido D), eu levei ela pro Pronto Socorro, como os enfermeiros trataram ela mal, dentro do Pronto Socorro e os médicos também, aquela coisa enquanto você não precisa de um serviço de saúde você, tá la numa esquina 'ai como é bonita, ai como é gostosa, ai como é linda' mas a partir da hora que você precisou, a discriminação é a primeira coisa que aparece,(Entrevista realizada com Margarida, em sua residência, no dia 6 de Agosto de 2011.)

geralmente eles não atendem, quando eles verem que é uma travesti, eles já falam 'ai, é um viado!! Já vai todo mundo para ver o viado ali, quer dizer em vez de atender, tentar ver qual é o problema, medicar, não primeiro todo mundo vem ver que é um viado, primeira palavra que você escuta 'sem vergonha tem que morrer mesmo' (Entrevista realizada com Margarida, em sua residência, no dia 6 de Agosto de 2011.)

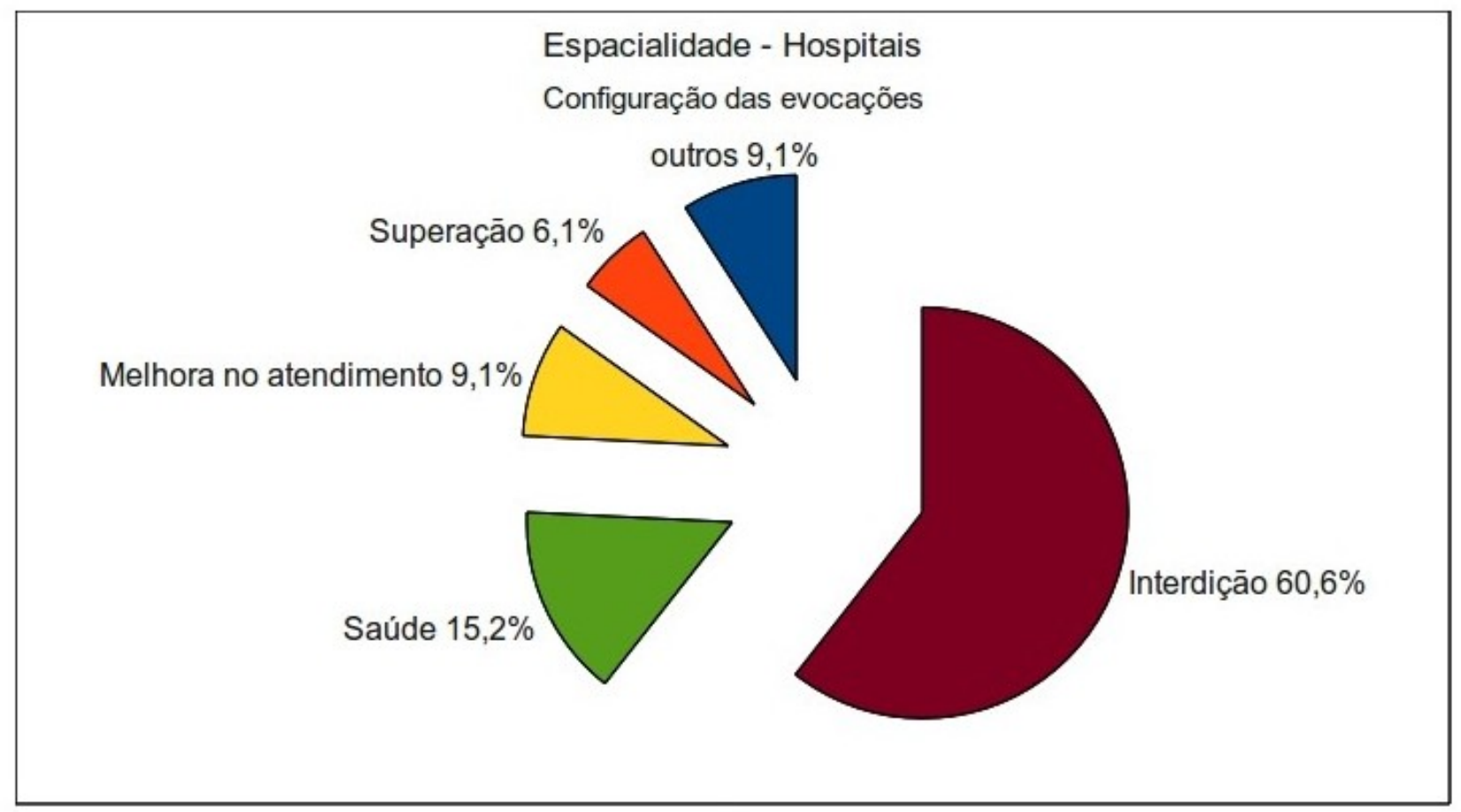

Gráfico 3 - Espacialidade - Hospitais: Configuração das Evocações.

Vinicius Cabral, J oseli Maria Silva e Marcio J ose Ornat 
Sobre o atendimento médico e hospitalar resultante de agressões físicas sofridas, também evidenciam-se relatos de interdição, como visto abaixo:

\section{(...) não procurara, não não procuraram. Só quando é um caso muito grave mesmo, ou alguém levá-las. Mas caso o contrario se tratavam em casa. Já vi vários casos de travestis que sofreram um tiro, e conviveram com um tiro no braço, e ficou com defeito no braço, a (nome omitido E) era uma. Ela morava na mesma casa que eu morava, ela tinha um defeitinho no braço, por ter levado um tiro e não ter procurado um médico por medo de ir no médico, ou procurar a policia porque poderiam perguntar como é que foi, $e$ aquele tempo era assim se agente procurasse a justiça, agente ficava presa lá, entendeu não tinha como (Entrevista realizada com Rosa, em sua residência, no dia 5 de Julho de 2012.)}

A 'Saúde' apresenta $15,2 \%$ do total de evocações sobre o hospital, e se relaciona a prestação de serviços vinculadas a saúde. Por outro lado, a categoria 'Melhora no atendimento' $(9,1 \%)$ aparece associada ao fato de que atualmente as instituições de direitos humanos e Ong's têm pressionado as instituições de saúde no cumprimento do atendimento digno. Um exemplo evidencia-se na fala de Rosa, uma travesti com 52 anos e que experienciou por vários anos os serviços públicos de saúde

ah hoje em dia tá bem melhor, hoje em dia tá bem melhor, antigamente eles não tavam nem aí, mas hoje em dia sim, hoje em dia se aparecer algum caso de violência eles procuraram atender bem, né eu acho que muita fundações tá em cima, dai eles tem medo de ser cobrado, então por isto eles estão atendendo melhor (Entrevista realizada com Rosa, em sua residência, no dia 5 de Julho de 2012.)

A 'Superação' é um elemento das representações sociais das travestis em torno dos hospitais e representa $6,1 \%$ do total de evocações desta mesma espacialidade. Ela se refere a um cenário após a violência e interdição, em que a vítima se recuperou e voltou ao hospital com o intuito de mostrar ao agressor desta violência psicológica e de negligência que ela estava viva:

eu acho que a pior que eu já passei foi esta que eu falei, aqui no hospital eu me vinguei do enfermeiro, porque eu fui lá e mostrei pra ele que eu tava de pé. Olhei bem na cara dele 'lembra que você falava que eu era viado e que tinha que morrer, aqui o viado aonde é que tá'. Daí o medico que tinha me atendido veio. (Entrevista realizada com Margarida, em sua residência, no dia 6 de Agosto de 2011.)

Por fim a categoria 'Outros' que apresenta $9,1 \%$ do total de evocações sobre o hospital foi criada para reunir relatos que não se enquadram em um eixo semântico. O que se pode afirmar é que as representações sociais construídas pelas travestis demonstram que o hospital, embora seja a espacialidade da saúde, onde pessoas possam se curar de suas enfermidades, e de outras lesões corporais, este acaba que não exercendo em sua totalidade esta função. Pelo contrário, são elementos de violência e interdição. $\mathrm{O}$ hospital é uma espacialidade que não foge às regras da sociedade heteronormativa que penaliza os 'corpos transgressores'.

Da mesma forma que em relação as espacialidades anteriores, a casa é uma espacialidade hegemônica na estruturação do discurso das travestis sobre a morte. Ela aparece ligada aos sentidos de velhice, família, violência, morte, a expectativa, a amizade, a não aceitação a família e outras representações. Evidenciamos abaixo os percentuais de cada elemento, através do gráfico 4 que remete a espacialidade da casa.

A 'família' corresponde a $20,6 \%$ do total de evocações, e aparece como uma categoria ambígua, pois se por um lado seria o grupo de pessoas que poderia se preocupar com as travestis em caso de violência e risco de morte, é também aquela que promoveu a sua vulnerabilidade, já que a maioria das famílias não aceitaram a identificação de gênero das travestis e as rejeitaram desde a adolescência. As falas estão repletas desse misto de mágoa e de amparo, como visto abaixo:

a minha família se preocuparia. Toda a minha família e os amigos também. (...) Então, se eu vou pra uma casa de uma amiga daí eles ficam preocupados porque dai eu não volto né, dai sim, eles ficam preocupados. Por eu sair e não voltar, eles já começam a procurar. Mas a sociedade acho que fala assim: é travesti, não tem importância nenhuma. Então a sociedade já é mais negativa. Agora a família e amigos, estes se preocupam (Entrevista realizada

Vinicius Cabral, J oseli Maria Silva e Marcio Jose Ornat 


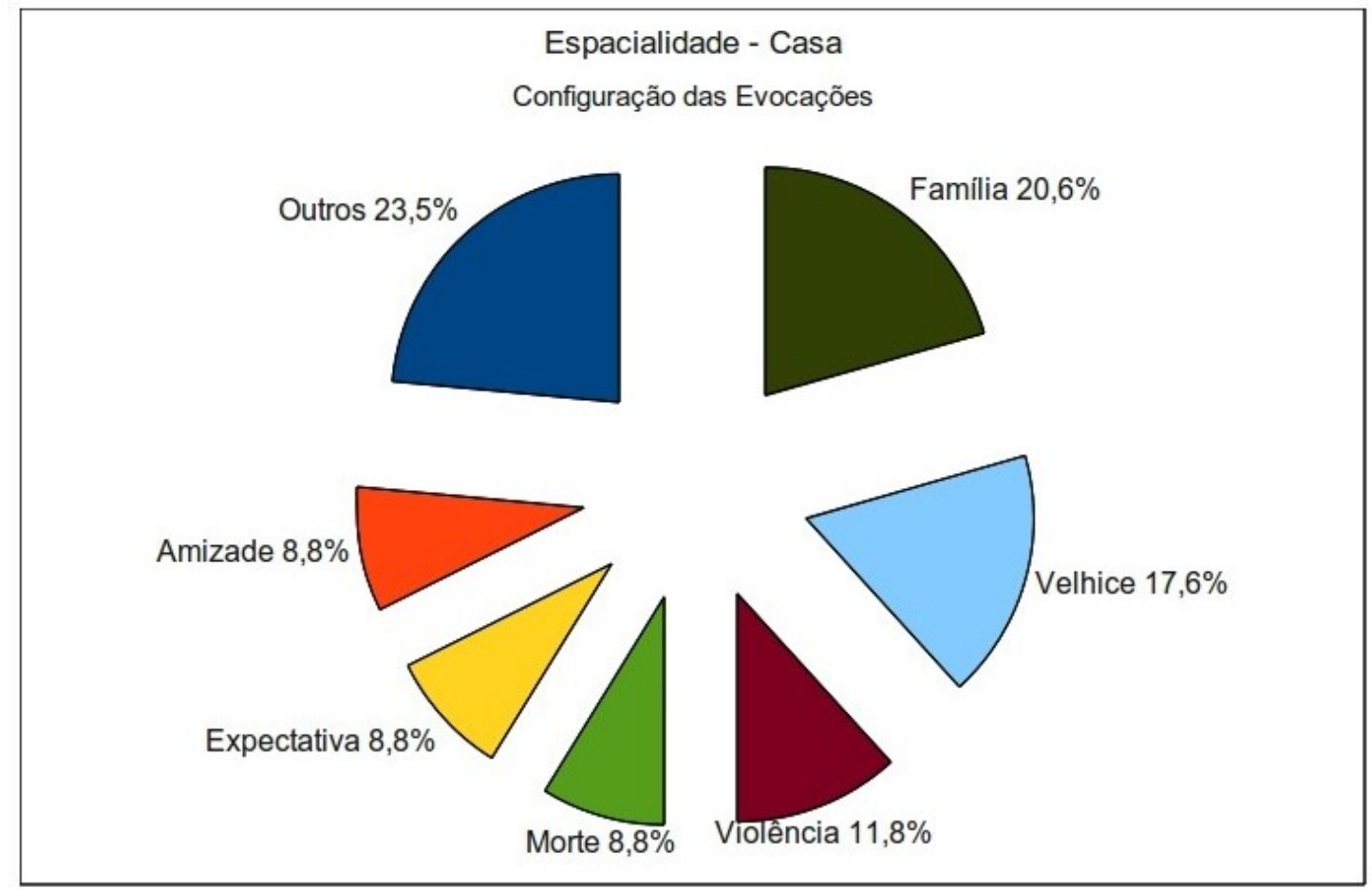

Gráfico 4 - Espacialidade - Casa: Configuração das Evocações

com Azaleia, no Grupo Renascer, no dia 8 de Dezembro de 2011.)

que tem muita travesti que sai de casa e a família não admite, de ter uma travesti dentro de casa (...) daí no dia que perde, valoriza e ficam sentindo, eu acho isso errado (...) (Entrevista realizada com Margarida, em sua residência, no dia 6 de Agosto de 2011.)

A categoria 'Velhice' é um elemento que compõe as representações sociais das travestis, através da espacialidade da casa. Ela representa 17,6\% do total de evocações em relação a esta espacialidade. A velhice através da casa é composta por duas frentes de representações sociais. Uma se refere as travestis mais novas e outra às travestis mais velhas. Para as mais novas a velhice é feita através dos objetivos traçados ainda na idade jovem. Já para as mais velhas, a velhice é o período em que elas não necessitam mais atuar na atividade da prostituição. Devido a grande violência e interdição que as travestis sofrem, poucas conseguem chegar a velhice. Vejamos os dois exemplos a seguir, sendo o primeiro de uma travesti com menos idade e a outra e uma travesti com mais idade:

(risos) ... sei lá, velha, feia sem dente (risos) ah mas eu quero estar bem, eu to tentando construir uma coisa agora pra mim e estar estabelecida no futuro, corro atras das coisas agora, como eu trabalho na rua indiferente disso, eu tenho um planejamento por de trás de tudo isto, todas tem alguma coisa, mas não precisa expor isto, eu sei que a beleza não dura pra sempre (Entrevista realizada com Violeta, em sua residência, no dia 30 de Maio de 2012.)

eu a minha velhice, eu pretendo continuar trabalhando porque agora eu tenho os meus cursos que eu fiz, continuar trabalhando, inventando alguma coisa se não eu vou trabalhar de diarista, ou fazer alguma coisa em casa, algum salgadinho pra vender pra continuar a sobreviver, se Deus quiser eu vou me aposentar ano que vem, pra viver, ter esta renda pra poder sobreviver, porque é o destino de todas, que nem eu acabei de falar a beleza, não é eterna, não é, passou aquela fase, porque fase mais linda, eu sou a única travesti de Ponta Grossa, a única, a que revolucionou esta cidade fui eu, e hoje em dia alguém lembra? (Entrevista realizada com Margarida, em sua residência, no dia 6 de Agosto de 2011.)

A 'Violência' é um dos elementos que compõe as

Vinicius Cabral, J oseli Maria Silva e Marcio J ose Ornat 
representações sociais da casa, e corresponde a 11,8\% do total de evocações. A violência ocorre por meio de outros indivíduos que agridem as travestis que estão em suas casas, usualmente através da violência psicológica, como pode ser observado na fala de Margarida:

ontem eu tava fumando cigarro na janela, porque agente não fuma cigarro aqui dentro de casa, por causa da minha mãe. E o lixeiro passou e eles sabem que aqui mora uma travesti. Eles tavam dentro do carro de lixo lá, não tenho nada com os gari porque é uma profissão digna como qualquer outra. Mas como eles viram que eu tava na janela, já começaram todos eles 'olha lá a bichona, olha lá o viadão, tá mexendo com nóis, tá querendo dar pra nóis!! Será que eu não tenho o direito de fumar um cigarro, na janela de noite, da minha casa? (Entrevista realizada com Margarida, em sua residência, no dia 6 de Agosto de 2011.)

A 'Morte' corresponde a 8,8\% do total de evocações sobre a casa. A representação social em torno da relação casa e morte está ligada à doença, ao contrário da relação entre morte e rua, relacionada à violência. Isso porque se trata de uma travesti com 52 anos e que atua muito pouco na prostituição, como podemos visualizar na fala de Rosa, quando questionada sobre seus pensamentos em relação à morte:

eu acho que é mais tranquila agora. Eu acho que é mais por doença mesmo, mas por violência não mais né. Antigamente talvez eu pensasse mais. Hoje em dia não. Hoje em dia eu penso naquela morte tranquila, né eu to sossegada na minha casa. (Entrevista realizada com Rosa, em sua residência, no dia 5 de Julho de 2012.)

A 'Expectativa' corresponde a 8,8\% do total de evocações sobre a casa, relacionando-se aos anseios da travesti sobre o futuro. Em um caminho distinto, a 'Amizade' corresponde a 8,8\% do total de evocações sobre a casa. A amizade se relaciona aos aprendizados com outras travestis, através da convivência das mesmas ao dividirem uma casa. Finalmente, os relatos esparsos que não puderam ser reunidos em um eixo semântico foram classificados como 'Outros' $(23,5 \%)$.

As representações sociais das travestis, através da casa demonstram que a velhice é a categoria discursiva mais representativa. Ela está associada a categoria 'expectativa' pois as travestis, buscam construir o futuro através de suas realidades atuais, pois como na fala de Margarida "a beleza não é eterna" e como a beleza as sustentam na prostituição, elas anseiam construir o futuro logo. Este futuro está na espacialidade da casa pois todas almejam sair da atividade da prostituição para ficar em casa. Outro elemento relevante está na relação entre a Casa e o Território através da Morte, pois esta na casa aparece como o desejo da morte serena. No entanto, como visto anteriormente a morte no território é marcada pela violência.

$\mathrm{O}$ discurso das travestis entrevistadas trazem outras espacialidades ligadas à morte. Embora elas não sejam centrais, devem ser consideradas como estruturadoras da relação entre espaço e morte que são a delegacia com $4,3 \%$ do total de evocações, boate com $3 \%$ do total, velório com $1,5 \%$ do total, $\mathrm{ONG}$ com $0,9 \%$ e vizinhança com $0,3 \%$ do total de evocações.

A delegacia é representada como uma espacialidade de 'Não justiça' que corresponde a 78,6\%, ao 'Medo' com 7,1\%, a 'Interdição' com 7,1\% e a 'Melhora no atendimento' que corresponde a 7,1\% do total de evocações sobre as delegacias. A boate corresponde a um elemento de quando as travestis são mais novas, e acabaram de sair de suas casas ${ }^{11}$. As representações sociais sobre esta espacialidade correspondem a 30\% de 'Prostituição', 20\% de 'Transformação do corpo', 10\% de 'Morte, 10\% de 'Controle' e $10 \%$ de auto cura. As representações sociais em torno da espacialidade do 'Velório' se constituem unanimemente através do elemento 'Amizade'. As ONGS aparecem como elementos de auxilio às travestis. As evocações sobre esta espacialidade se concentram em 33,4\% morte e $66,6 \%$ militância LGBT. A militância em torno da luta por direitos humanos e a morte digna é uma luta relacionada à Ong's. Já a vizinhança, representando 0,3 $\%$ das evocações aparece como espaço de fofoca e sofrimentos pelas críticas e xingamentos.

Toda a convivência com o grupo de travestis, ao longo do processo de pesquisa evidenciou que a mesma sociedade heteronormativa que exclui as travestis da maioria das espacialidades de convivência social cotidiana diurna possibilita a constituição dos territórios da prostituição, agora durante a noite. Esta evidência relaciona-se nitidamente à discussão referente ao poder normativo visto em Foucault (1988), pois as relações de poder não constituem uma contraposição simples entre grupos de dominadores e grupos dominados, ou em outras palavras, grupos com práticas que correspondam à linearidade entre sexo, gênero, prática sexual e desejo, de um lado, e grupos com gênero e sexualidades dissidentes, de outro, mas pelo contrário, complexidades existenciais e espaciais.

Vinicius Cabral, J oseli Maria Silva e Marcio J ose Ornat 
Esta complexidade será problematizada na próxima seção, referente a relação entre território da prostituição e morte.

\section{Território da Prostituição Travesti e Morte como Elemento Estrutural do Discurso das Travestis}

Como visto anteriormente, a prostituição é resultado de várias interdições espaciais ao longo da vivência travesti. A interdição espacial é resultado do conflito existente entre a sexualidade travesti e a heteronormatividade hegemônica do espaço geográfico, conforme argumenta Valentine (1993). Nas discussões anteriores evidenciamos que a vivência das travestis é repleta de exclusão e preconceito. Diversos espaços, necessários para a conquista de direitos sociais como hospitais, delegacias, e escolas ${ }^{12}$ aparecem como espacialidades interditas. A maioria das travestis, após serem excluídas da convivência com a família, possuem como única possibilidade de ocupação a prostituição. São raros os casos em que as travestis ocupam atividades fora do mercado sexual. A fala de Tulipa ilustra a realidade de não aceitação familiar de sua condição sexual e quando questionada sobre o afeto e o sentimento de falta que sua família poderia sentir, no caso de sua morte, ela argumenta:

minha família faz mais de vinte anos que não há vejo, nem minha mãe, meu pai é falecido. Eu sou de Maringá, minha mãe tem uma condição financeira boa, só que nunca me ajudou. Eu morei na rua, eu fui mendiga, então eu tive que optar pela prostituição para mim sobreviver. Mas minha família, eu não procuro eles, eles não me procuram. A última vez que eu procurei eles vai fazer mais de 20 anos e minha mãe me via e só chorava. Ela dizia assim que o filho dela não era o filho dela, porque a gente muda, né. Então ela achou estranho, ela pensou que era um homenzinho que ia chegar, e viu chegando uma mulher. Então, para eles é estranho, e também eles não aceitam . (grifo nosso) (Entrevista realizada com Tulipa, no Grupo Renascer, no dia 7 de Dezembro de 2011.)

Portanto, as representações sociais das travestis sobre o território da prostituição estão estruturadas sobre os seguintes elementos que compõem o território, como podemos visualizar através do gráfico 5 abaixo:

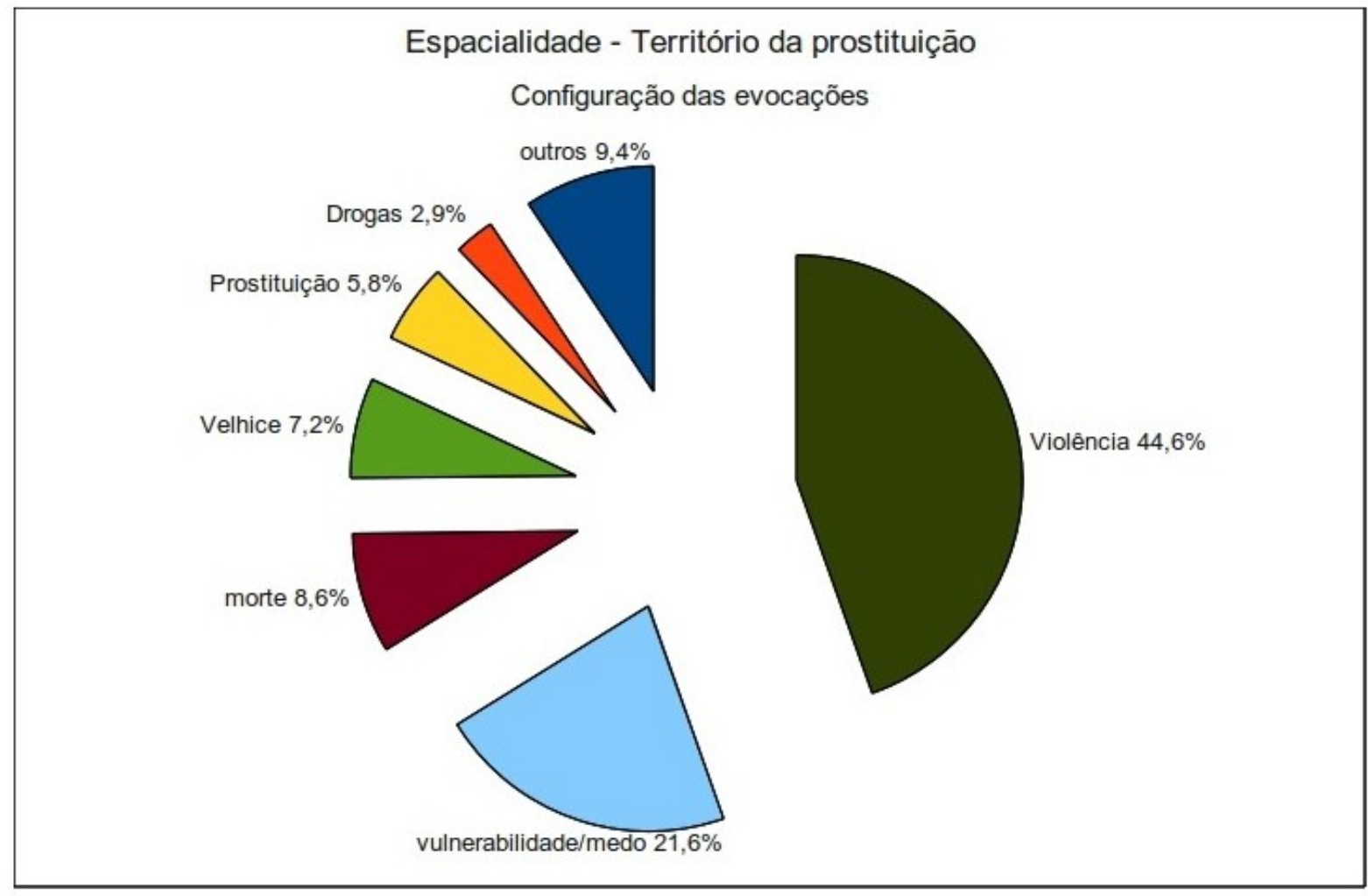

Gráfico 5 - Espacialidade - Território: Configuração das Evocações.

Vinicius Cabral, J oseli Maria Silva e Marcio J ose Ornat 
A violência física, que corresponde a toda manifestação com o objetivo de ferir, pode ser observado através dos relatos de Iris e Margarida, em que ambas relatam suas experiências de violência física sofridas no território da prostituição:

(...) a primeira que foi o tiro que eu levei no pescoço. Foi de um cliente. Sabe, assim, nós fizemos o programa e depois ele disse que não ia me pagar, e atirou achando que ia me matar. Mas ele não conseguiu me matar e a segunda, eu tava na esquina, parou um carro, cheio de milico e me botou pra dentro $e$ do carro e começaram a me esfaquear dentro do carro. Começaram a me esfaquear, aí também graças a Deus não morri. (...) Eu levei 13 facadas (Entrevista realizada com Iris, no Grupo Renascer, no dia 7 de Dezembro de 2011.)

(...) em 2007 eu sofri uma violência muito grande aqui em Ponta Grossa. Eu saí para fazer um programa com 4 clientes $e$ quebraram minha costela, furaram meu pulmão, quebraram mеи maxilar, quebraram todos os meus dentes, queimaram meus pés, me afogaram na poça d'água, 'me mataram' você entendeu? Dai (...) pediram para a presidente do Renascer que fosse fazer reconhecimento de uma travesti que tava morre, não morre, porque o médico deu três dias de vida para mim de tão agredida que eu fui (Entrevista realizada com Margarida, em sua residência, no dia 6 de Agosto de 2011.)

A violência sexual, ocorre quando o agressor abusa de seu poder sobre a vítima na obtenção da gratificação sexual, sem o consentimento da mesma. Ela está associada a violência física e psicológica. A violência sexual pode ser observada abaixo nas falas de Tulipa:

(...) eu já fui estrupada. Faz anos já. Eu saí com um cara e ele tava nestas bestas, carrão tipo furgão. Daí eu achei que era só ele que tava ali, daí quando eu fui ver, quando eu olhei pra trás tinha mais cinco. Daí eu tive que dar pros cinco. Eles me levaram lá no centro de eventos, naqueles matos bem pra lá. Daí eles fizeram o que quiseram comigo, chegaram a me machucar. Até porque fiquei sangrando. A minha parte íntima sangrou. Eu tive que ir no médico pra costurar. Rasgaram, até porque era um atrás do outro. Daí me deixaram no meio da rua toda machucada sangrando as pernas, assim foi horrível. Só esta vez mesmo (Entrevista realizada com Tulipa, no Grupo Renascer, no dia 7 de Dezembro de 2011.)

(...) daí ele pegou a Iris. Ela foi estrupada por 5. Fizeram ela beber, dai foi estrupada. 2 horas eles ficaram transando com ela $e$ fizeram ela beber, e estragaram todo o carro dela. Era o fusca que ela tinha na época, abriram o negócio do fusca atrás, $e$ tiraram todos os fios. Ela fez isto para me proteger, porque ela falou, vai Tulipa, vai embora, que o fulano tá vindo, hoje em dia ele não me conhece porque eu tô de cabelo liso, e era enrolado, eu era mais magra agora eu tô gordinha, então ele não conhece (Entrevista realizada com Tulipa, no Grupo Renascer, no dia 7 de Dezembro de 2011.)

A violência psicológica, caracteriza-se pela humilhação, desrespeito, rejeição, entre outros. Na vivência travesti esta violência é mais frequente que as demais, considerações estas evidenciadas nas falas de Rosa e de Jasmim:

(...) eles queriam irritar. Passavam e gritavam "o João vamos jogar bola”. Sabe, tipo de coisas assim. Quando eles sabiam que era travesti, daí eles falavam "pra jogar bola", "filha a puta". Outros eram mais agressivos, ou mandavam criar vergonha, caçar um trabalho, sabe este tipo de coisa assim. (...) Outros jogavam caixinha de leite, jogavam água ou sei lá o que, se era xixi ou não era. Mas jogavam, era mais este tipo de agressão. (Entrevista realizada com Rosa, em sua residência, no dia 5 de Julho de 2012.)

(...) de você estar trabalhando e eles passarem jogando ovo, extintor, chegam ao ponto de jogar fezes e urina em você. Chegam a este ponto (...). E dai você não pode reagir, bater, jogar pedra, porque a qualquer momento eles podem voltar e te matar. Então você tem que aguentar isto quieta, né. Apesar de que muitas são revoltadas, ficam loucas, pegam pedras $e$ atacam mesmo. Eu sou uma né, que imagina

Vinicius Cabral, J oseli Maria Silva e Marcio J ose Ornat 
eu tô quieta ali. Aí passam e jogam um ovo. $O$ que você vê, você joga. Aqui, mês passado, eles tavam jogando bomba, bombinha, aquelas bombas que explodem. E vai que um troço deste pega no teu olho? Eles não pensam, mas em Curitiba é maior do que aqui. (Entrevista realizada com Jasmim, na casa de violeta no dia 30 de Maio de 2012.)

Como visto anteriormente, a violência contra o grupo de travestis é resultado da homofobia, ou mais especificamente em relação ao grupo escolhido para esta reflexão, referente a transfobia.. Como analisado por Bryant e Vidal-Ortiz (2008), a palavra 'homofobia' tem se colocado tanto como uma ferramenta conceitual quanto como um recurso discursivo das pessoas que não se alinham as normas de gênero e sexualidade, como evidenciado através do grupo de travestis. Como apontado pelos autores, a forma como a homofobia tem sido pensada pelas ciências sociais aponta para o fato de que ela é produzida por intersecções de outros vetores de relações de poder, como as relações interseccionais que ocorrem a partir de grupos de renda e questões étnicas e raciais.

Segundo os autores, este termo foi cunhado por George Weinberg (1972) em seu livro 'Society and the Healthy Homosexual', tratando tanto das relações de outros grupos com relação aos homossexuais, quanto das relações intra-grupo. Mesmo tendo sido cunhado a partir da Psicologia, consideramos que estas relações homofóbicas, ou especificamente a partir de nossa problemática, de relações transfóbicas, ocorrem através das espacialidades, como evidenciado tanto na discussão de Mott, Cerqueira e Almeira (2002) como de Cabral, Ornat e Silva (2011). Assim, a homofobia entende-se como atitudes e ações excludentes em relação aos homossexuais, baseadas em considerações da homossexualidade e dos homossexuais, em suas mais variadas existências, como desviantes, doentes, perversos, pecaminosos, imorais, corruptos e assim por diante, sofrendo a partir disso as mais variadas sanções.

Sobre estas ações, Tulipa evidencia a dificuldade que a sociedade tem de desvincular os significados hegemônicos do corpo sexuado em uma sociedade heteronomativa e as múltiplas possibilidade de expressão generificada: "Ah eles acham errado, que nem eu falei, eles acham que a travesti, transsexual, tem que ser homem, porque quem nasceu homem tem que ser homem".

Outro elemento que se relaciona a categoria discursiva 'Violência', através do território da prostituição travesti é a forma como a violência é praticada. Para as travestis existe uma diferença na forma em que homens e mulheres praticam a violência contra elas. Esta violência sendo produzida através da identidade de gênero do agressor, pode ser observada na fala de Tulipa, ao ser questionada sobre as diferenças de atos de violência praticados por homens e mulheres:

Mais homens. Mas tem mulheres também, mas poucas. As mulheres praticam mais, quando estão com os homens, né. Eu já vi caso de homofobia que elas jogavam lixo, extintor, porque elas estão junto com os rapazes, mas sozinha, eu acho que só vi uma vez, em toda a minha vida. Ela veio me xingar assim, e passou dando risada, assim, só assim mesmo, uma vez que eu vi. Mais vezes que vi foi homem. Jogam lixo, jogam ovos, jogam limão, passam xingando, jogam pedras. Se bobear, eles descem do carro com pedaço de pau pra dar em você. Todas as formas que você imaginar contra as travesti eles podem fazer (Entrevista realizada com Tulipa, no Grupo Renascer, no dia 7 de Dezembro de 2011.)

A 'Violência' é o elemento de maior representatividade dentro do território. Ela está estruturada principalmente através da violência física, sexual e psicológica. Esta violência é o resultado da não tolerância do agressor sobre a não linearidade entre sexo, gênero, desejo e prática sexual da vítima. A violência ainda é relatada pelas travestis como sendo diferenciada, pois há diferenças entre homens e mulheres que praticam atos de violência contra as travestis.

A 'Vulnerabilidade/medo' é o segundo maior elemento de intensidade nas evocações que constituem as representações sociais das travestis, sobre o território da prostituição, com 21,6\%. Embora a categoria seja composta por dois elementos a 'vulnerabilidade' e o 'medo', elas foram agrupadas porque estão vinculadas e eram evocadas de forma conjunta. As travestis sentem-se vulneráveis à morte no território da prostituição e tal sentimento está entrelaçado com o medo.

A 'vulnerabilidade/medo' é um afeto presente no cotidiano das travestis e é marcante a sua relação com o território de prostituição. Em geral, a vulnerabilidade é evocada quando elas relatam a morte ou a violência ocorrida com amigas ou colegas. Algumas vezes presenciam o fato e outras ficam sabendo por meio de uma rede de comentários e notícias em jornais que publicam mortes violentas de travestis nas ruas das

Vinicius Cabral, J oseli Maria Silva e Marcio J ose Ornat 
cidades. A cada situação de morte ou violência que é presenciada ou conhecida pelas travestis, elas sentem medo e pensam em sua própria vulnerabilidade à morte violenta. Os trechos de fala que se seguem, de Iris e Rosa, revelam a vinculação entre vulnerabilidade e medo da violência e a possível morte, associada ao território da prostituição, quando elas foram questionadas sobre a relação entre vulnerabilidade ao risco de morte e espaço urbano:

(...) na rua, na rua com certeza. (...) Eu acho que é a rua porque a gente fica mais a mercê, e ali a gente lida com todo o tipo de gente. Então a gente não sabe qual o carro que a gente vai entrar. A gente sabe que vai entrar, mas se vai voltar, a gente não sabe. Então é uma corda bamba (Entrevista realizada com Iris, no Grupo Renascer, no dia 7 de Dezembro de 2011.)

(...) eu acho que na rua. Medo! Pavor! Agonia!(Entrevista realizada com Rosa, em sua residência, no dia 5 de Julho de 2012.)

A 'vulnerabilidade/medo' também aparecem nos relatos em que elas associam ao risco de morte e ao sofrimento de violência ou tortura, elemento bastante comum nas mortes de travestis nos territórios da prostituição, conforme evidenciado nos relatórios anuais do Grupo Gay da Bahia. As mortes das travestis estão associadas aos requintes de crueldade e elas sabem que são alvos da violência de grupos transfóbicos. Nesse sentido, a 'vulnerabilidade/medo' aparece no sentido de ter a consciência de sua exposição ao risco de morte no território da prostituição, mas também ao ódio de que são alvo. $\mathrm{O}$ relato de Jasmim é ilustrativo da associação entre morte e violência:

Na verdade eu não tenho medo de morrer, se chegar e matar, matou! Mas é da tortura. É tenho pavor a tortura. Eu nunca sofri, já tive um pouquinho de experiencia, mas deve ser isto. Que nem foi aquela menina que sofreu a agressão, que era mulher mesmo, mulher de programa. Morreu com 21 anos. Que levaram lá no parque dos pinheiros e mataram. Torturaram ela, e ela foi lá viva. Arrancar a tua cara, o teu olho, e o que é isto? Tortura! (...) Se te matam e começam a te depenar, beleza, você tá morta! Agora, você em vida ver teu olho sendo arrancado, teu coro cabeludo, tua pele, teu seio? Tá loco! Deus me livre! (Entrevista realizada com Jasmim, na casa de violeta no dia 30 de Maio de 2012.)

A 'vulnerabilidade/medo' corresponde ao segundo maior elemento representativo sobre o território da prostituição travesti. Esta categoria se relaciona a posição de vulnerabilidade da travesti frente ao cenário de violência e de morte, presentes tanto no Brasil, como na cidade de Ponta Grossa.

A referência direta da categoria 'Morte' é o terceiro elemento mais representativo sobre o território da prostituição travesti e foi evocada em um contexto de lembranças que emergiram durante o manuseio de fotografias que as travestis guardam das amigas que fizeram durante sua trajetória de vida. As fotos mostradas por elas são repletas de falas sobre saudades, pesar e até mesmo admiração, quando comentam a realidade vivenciada pelas 'falecidas'. Além disso, aparecem as estratégias utilizadas pelas travestis para tirar vantagens dos clientes e o aumento de risco de sofrer represálias. É interessante observar que antes das depoentes falarem o nome da travesti que é o exemplo de morte, o termo 'falecida' aparece com frequência, adjetivando a travesti. Os relatos de Violeta e Rosa são ilustrativos nesse sentido, enquanto elas manuseavam as fotos para falar de sua trajetória de vida e as experiências de morte:

(..) Tem uma aqui em Ponta Grossa que morreu assim. A falecida (nome omitido $N$ ). (...) Ela era das antiga, já vai fazer uns oito anos que ela morreu. Só que ela era muito respeitada aqui também. Com a gente assim ela não era muito bruta, ela era de mexer com as novinha. Se tivesse uma novinha, ela já começava. Mas com o passar do tempo, ela se acostumava com você e não mexia mais com você. Mas de bater, de roubar, isto ela não aprontava. Era mais assim com os cliente. Daí ela saiu com o cara, daí o cara na 'entrevista' achou que era mulher. Só que achou que ela era alta. Tem travestis que você se confunde, mas ela tinha 'três metros de altura'. Tem travestis que tem rostos que confundem. Mas aquilo era desculpa, que nem o Ronaldinho lá, saiu com a moça lá e achou que era mulher? Não tem esta! Dai tá, ele saiu com ela, fez o programa lá. Só que acho que ele sentiu falta da carteira dele, daí se pegaram os dois no braço. Dai ele não conseguiu pegar a carteira dela, porque no braço não tinha quem podia pra (nome omitido N). Ela já bateu em 2

Vinicius Cabral, J oseli Maria Silva e Marcio J ose Ornat 
Policiais Militares, para você ter ideia. Daí o cara não pode com ela. Volto na casa, pegou um revolver e voltou, e no que ele voltou ela tava sozinha na esquina. Ele pediu de novo a carteira, ele não queria o dinheiro, queria a carteira por causa dos documentos. Dai como ele sabia que não podia com ela no braço, ele deu um tiro na perna, e outro na testa, que acabou matando ela. Mesmo assim não conseguiu a carteira, acho que ele se apavorou e foi embora sem a carteira. Daí ela foi pro IML. Daí quando tiraram a roupa dela, a carteira dele tava dentro da luva dela, e foi a partir dali que conseguiram o endereço dele. Tava ali identidade, CPF, tudo ali dentro da luva. Daí, eles conseguiram o endereço dele, chegaram em casa e ele tava dormindo ao lado da esposa. Ele ficou preso três dias e já foi solto. Acho que pagaram uma fiança de três mil reais. Acho que foi a mãe dele que pagou. Ela com dois metros de altura e o cara que matou ela tinha a minha altura, de um e cinquenta e seis. Mas ela era terrivel (Entrevista realizada com Jasmim, na casa de violeta no dia 30 de Maio de 2012.)

\section{(...) Ah, são tantas! Tantas! Teve tantas} tantas tantas! Tiveram sim. Nossa! Tem várias travestis assassinadas com um tiro, que tava na esquina, homem passava e dava tiro, ou mesmo apanhava até morrer, ou eram encontradas, corpo jogado. A última foi a Margarida. A Margarida aqui em Ponta Grossa. Esta barbaridade que aconteceu com ela né, há uns 3 anos atrás. A última foi ela. (Entrevista realizada com Rosa, em sua residência, no dia 5 de Julho de 2012.)

A 'morte' é evocada para descrever o fato ocorrido, como sendo o ápice da violência. Contudo é importante ressaltar que as categorias apresentam-se totalmente conectadas entre si. Morte, violência e vulnerabilidade/medo fazem parte da configuração de uma rede de sentidos que faz do território da prostituição o grande paradoxo vivido pelas travestis. Em uma sociedade heteronormativa há a interdição da vivência travesti em todas as espacialidades que lhes possibilitaria acesso à uma vida cidadã. Essa mesma sociedade permite sua existência como prostitutas e isso significa que há desejo pelos seus corpos, práticas e fantasias e é assim que o território da prostituição travesti ganha um sentido e a possibilidade de existir socialmente. Assim, simultaneamente, o território da prostituição significa possibilidade de existência e de morte, compondo uma complexa e paradoxal espacialidade no universo simbólico do grupo de travestis entrevistadas.

A 'Velhice' é um elemento periférico ligado à morte. Embora, em geral, o estado da velhice seja uma aproximação da morte, essa vinculação não é central para o grupo de travestis. O processo de 'extremo' envelhecimento não é comum entre elas. A mortalidade das travestis é precoce pela sua vulnerabilidade social e o pequeno acesso que têm aos bens e serviços urbanos. Os argumentos precedentes já evidenciaram os riscos, privações e interdições a que elas estão sujeitas a vida toda e isso gera uma expectativa de vida baixa. Não é comum encontrar travestis velhas e elas têm consciência de uma vida curta. A percepção de uma vida curta, sem muitas expectativas de progresso social, sujeitas a toda sorte de violência e medo, faz com que elas vivam o presente com toda a intensidade, sem se preocupar com o futuro. A fala de Iris é ilustrativa no sentido de não pensar em um futuro como uma pessoa que irá chegar à uma idade avançada:

Olha, se você me perguntasse uns dez anos atrás, eu não me veria há dez anos atrás com trinta anos. Eu nem achei que chegaria aos quarenta anos. Hoje, com quarenta anos eu já tenho uma perspectiva de vida mais avançada que eu tenho condições de alcançar a velhice, porque eи sou uma das poucas. Eu acho que aqui em Ponta Grossa tem três travestis que fazem parte desta população que está entrando na 'terceira idade' porque eu to com quarenta anos, mas eu to quase lá. Aqui em Ponta Grossa deve ter umas trinta travestis, mas acho que só três que chegou até esta idade (Entrevista realizada com Iris, no Grupo Renascer, no dia 7 de Dezembro de 2011.)

A 'Velhice' tem um forte impacto na atividade de prostituição, pois a energia e a beleza são elementos fundamentais na competição pelo cliente e, por consequência, pelos lucros da atividade comercial. A beleza que é um atributo importante na competição entre as travestis na conquista de clientes também é resultado de muitas transformações corporais que as coloca em risco de morte. Elas utilizam uma série de ações de intervenção no corpo como a injeção de silicone industrial que é altamente perigoso à saúde. $\mathrm{O}$ relato de Margarida, uma travesti que já possui 48 anos

Vinicius Cabral, J oseli Maria Silva e Marcio J ose Ornat 
é reflexo de sua experiência de rejeição pelos clientes e as dificuldades financeiras de quem sobrevive da atividade comercial sexual:

A sociedade empurra nós para onde? Pra rua, pra se prostituir. Enquanto você tá bonita, tá se arrumando bem que você não tá se drogando, nossa você é maravilhosa. Depois que chega 20 anos, já tá bonitinha remediada. 30 anos, já começa o negócio ficá meio. Daí aparece outras novas. Daí o que os clientes vão fazer? Vão ficar com as novas e vão deixar as que têm uma idade mais avançada de lado. Daí você não tem opção, daí você vai desanimando, e vai desistindo de viver, porque é horrível (...) (Entrevista realizada com Margarida, em sua residência, no dia 6 de Agosto de 2011.)

A 'Prostituição' logicamente é a atividade que dá sentido ao território, a partir da apropriação realizada pelas travestis em relação a cidade. Contudo, a prostituição, quando associada ao risco de morte, aparece como uma representação periférica, já que esta é a atividade que lhes permite a sobrevivência. Assim, o impacto da velhice na vida de uma travesti que vive da prostituição a leva a tentar outras alternativas, embora menos rentáveis, como relata Margarida: "me prostituindo não me prostituo mais, porque ninguém me olha mais. Não tem jeito, né porque já deu o que tinha que dar e não adianta a gente querer forçar também". (Entrevista realizada com Margarida, em sua residência, no dia 6 de Agosto de 2011).

As 'Drogas' são um elemento que compõe as representações sociais das travestis sobre o território. O uso de drogas é relatada como experiência própria ou pelo uso que os clientes fazem da droga em sua presença durante o desenvolvimento do programa sexual. Os clientes, muitas vezes, buscam a droga com as travestis para não recorrer diretamente ao traficante. Além disso, as travestis podem se constituir em companhia para o uso de drogas ou até mesmo em proteção para o caso de algum problema de saúde. Jasmim relata a utilização de drogas por parte de alguns clientes

eu já saí com vários. Eu to indo aí, mas eu fumo crack, posso ir aí fumar? Pode vir amor, só que eu não fumo. Você fica comigo, faz o programa. (...) Outros que vem $e$ dizem: Oh Jasmim, eu trouxe você aqui, mas eu vou dar uma bola, quer experimentar? Não obrigado, fique a vontade, nada contra. Mas assim do cara forçar a fumar, isto nunca me aconteceu (Entrevista realizada com Jasmim, na casa de violeta no dia 30 de Maio de 2012.)

As representações sociais das travestis em torno das drogas se relacionam ao caso de travestis, colegas de trabalho, que perderam suas vidas devido ao uso de drogas. Além disso, há uma preocupação com as gerações mais novas pelo uso sem controle da droga. Jasmim e Margarida relatam a perda de amigas pelo uso indiscriminado de drogas e seus perigos para as travestis jovens:

quem morreu por último foi a (nome omitido O). (...) mas foi por causa de drogas. Começou dar uns derrame. Daí, na terceira vez deu uma parada nela. Daí ela já morreu. Mas por causa de droga. Hoje em dia, elas tão usando drogas muito cedo. As que tão no começo, começando a ser travesti já estão começando a experimentar o fim da carreira. Elas tão começando de trás para frente. Não que a gente no final da carreira vá usar, mas elas estão usando muito cedo. Elas caem no mundo da prostituição e já começam a usar drogas, são muito novas para isto (Entrevista realizada com Jasmim, na casa de violeta no dia 30 de Maio de 2012.)

a (nome omitido O) usava muita droga, como tem muitas que ainda usam aquilo na nossa cidade. Mas quem é a gente pra dizer: você não pode ser assim, você não pode. Lógico que a gente aconselha pra elas não usar. Eu já fui dependente química, já fui usuária. Hoje em dia eu não bebo. A única droga que eu uso é o cigarro. Não sinto falta nenhuma. Eu vejo as pessoas perdida e me cortam o coração. Porque saber que o destino de todas é o mesmo, é a morte não adianta. Porque ou você fica devendo demais pro traficante, ou você vai roubar uma coisa e vai morrer, ou o traficante vai te matar, porque você tá devendo demais. (Entrevista realizada com Margarida, em sua residência, no dia 6 de Agosto de 2011.)

Por fim, na categoria 'Outros' houveram várias evocações isoladas que não constituíram um eixo discursivo e assim, não há como analisar esse grupo de informações de forma coerente. Apesar disso, há um aspecto que merece especial atenção. Houve apenas

Vinicius Cabral, J oseli Maria Silva e Marcio J ose Ornat 
uma evocação que esteve atrelada à expectativa de futuro fora do mundo da prostituição e isso significa a pouca esperança das travestis traçarem uma perspectiva de vida que não esteja atrelada ao risco da violência, doença e uma baixa expectativa de vida.

A análise evidencia que há um núcleo representacional composto por violência, vulnerabilidade/medo e morte. Esses elementos são interdependentes e constroem o sentido da representação criada pelas travestis em relação ao território da prostituição. Outros elementos componentes da representações da relação entre espaço e morte, vinculados ao território, são periféricos como a velhice, a prostituição e as drogas. A velhice não é uma expectativa do grupo das travestis. A prostituição está relacionada à possibilidade de vida e as drogas parecem ser um mal que já faz parte de sua realidade, cada vez mais cedo. Enfim, o território da prostituição foi a espacialidade hegemônica ligada ao risco de morte para o grupo social investigado. Paradoxalmente, é a partir da existência do território que lhes é permitido viver. Assim, as travestis existem em nossa sociedade heteronormativa e transfóbica, permanentemente sendo levada à morte.

\section{Considerações Finais}

A presente reflexão evidenciou a relação entre espaço e morte nas representações sociais de travestis em Ponta Grossa - Paraná. O processo investigativo evidenciou que o espaço geográfico se produz pela lógica da sexualidade heteronormativa, conforme apontado por Valentine (1993). Assim, as pessoas que não se enquadram nesta sexualidade hegemônica vigente, como é o caso do grupo das travestis, são punidos com interdição, violência e a própria morte. A vivência espacial travesti é repleta de sofrimento resultante do processo de interdição espacial, conforme aponta Silva (2009). As travestis são interditas à educação e ao trabalho formal, tendo a prostituição como uma das poucas ocupações que a sociedade heterossexual lhes permite, para que possam obter dinheiro para sua existência.

Há certas espacialidades urbanas que são marcadamente relacionadas à morte ao grupo de travestis, como é o caso dos hospitais e da casa. Esses espaços, em geral, são sinônimos de cura, cuidado e proteção. Para as travestis, esses significados não correspondem à realidade por elas vividas, pois estão vinculados à interdição e preconceito. Outras espacialidades que foram marcantes no discurso das travestis na relação entre espaço e morte foram a delegacia, boate, velório, ONG e vizinhança. As travestis não interpretam as instituições de justiça, cuidado e conhecimento como sinônimo de vantagens ou direito social. Pelo contrário, sua vivência é de não acesso à justiça e conquista de direitos cidadãos.

$\mathrm{O}$ espaço de maior vinculação com a morte no discurso das travestis foi o território da prostituição. É através das experiências vividas na atividade de prostituição que são relatados a maior parte de riscos, vulnerabilidades e medos relacionados à morte. Contraditoriamente, o território da prostituição é também sua possibilidade de existência em uma sociedade transfóbica. Portanto, o território da prostituição é um espaço complexo que articula tanto a vida como a morte do grupo de travestis.

A cidade pode ser interpretada de inúmeras maneiras por diferentes grupos sociais, conforme argumenta Duncan (1990). O grupo de travestis interpreta a cidade por meio da dor, preconceito, violência e exclusão. Construir a visibilidade de sua versão do espaço urbano é uma forma de lutar por uma sociedade mais humana e justa, capaz de conviver com a pluralidade social.

\section{$1 \quad$ Prins e Meijer, 1998.. \\ 2 Tradução de transgender, termo genérico para o contexto Anglófono, para se designar às 'travestis' e transexuais}

\section{MOSCOVICI, Serge. A representação social da psicanálise. Rio de Janeiro: Zahar, 1978.}

$4 \quad$ O nome presente nesta tabela não é o nome real da travesti, esta escolha é motivada com o intuito de proteger a fonte, desta os nomes aqui presentes serão seus novos nomes ao longo deste trabalho

$5 \quad \mathrm{O}$ termo transexual aparece para designar algumas entrevistadas, pois no ato da questão "você se identifica como?" elas responderam transexual, no entanto a convivência de mais de três anos com o grupo revela que algumas entrevistadas embora ora se definam como travesti, ora como transexual, no fim acabam que por se definir como travesti, pois segundo suas falas ainda não realizaram a cirurgia de transgenitalização.

6 O campo produziu um total de 4 horas 48 minutos de fala. .

7 A categoria 'espacialidade não evidente' foi descartada desta análise, mas ainda é feito sua menção no intuito de demonstrar que existem mais

Vinicius Cabral, J oseli Maria Silva e Marcio Jose Ornat 
espacialidades que remetem a morte das travestis, mas não ficaram claras na fala das entrevistadas.

$8 \quad$ Embora a maior parte das travestis esteja no centro da cidade, existem outras possibilidades espaciais da prostituição. Os exemplos são a BR e as boates, em que ocorrem ainda atividades da prostituição travesti em menor número em relação ao centro da cidade.

9 Conforme Ornat (2008) as travestis quando surgiram na cidade compunham um total aproximado de setenta a oitenta pessoas, que trabalhavam em um local denominado Posto Presidente, que se situava no bairro da Nova Rússia. No entanto, como a atividade da prostituição pressupõe movimento, as travestis se movimentaram em direção ao centro do espaço urbano.

10 Todos os nomes, quando específicos a um sujeito e citados pelas travestis serão omitidos, no intuito de proteger estes sujeitos.

11 Esta realidade corresponde a uma lógica mais antiga da relação entre a exclusão da casa e a ida a boate. Hoje em dia, as travestis mais novas, quando se assumem como travestis e acabam sendo expulsas de casa, procuraram ficar na casa de travestis mais velhas, e começam a se prostituir na rua. Quando estão na rua elas podem ficar, com a travesti que a acolheu, ou ter o seu próprio espaço dentro do território da prostituição, desde que este seja mais distante das travestis mais velhas.

$12 \quad$ Ver proposta de Silva (2009)

\section{Referências}

ARIÉS, Pilippe. Sobre a história da morte no ocidente desde a idade média. Lisboa: Teorema, 1975

BRYANT, Karl; VIDAL-ORTIZ, Salvador. Introduction to Retheorizing Homophobias Sexualities, vol. 11, n ${ }^{\circ}$ 4, p. $387-396,2008$.

BUTLER, Judith. Problemas de Gênero: feminismo e subversão da identidade. Rio de Janeiro: Civilização Brasileira, 2003.

BARDIN, Laurence. Análise de Conteúdo. Lisboa: Edições 70, 1977.

CABRAL, Vinicius; ORNAT, Marcio Jose; SILVA, Joseli Maria. Algumas Considerações sobre as
Relações entre Espaço, Violência e a Vivência Travesti na Cidade de Ponta Grossa - Paraná . Geografia UFPI, vol. 9, nº 31, p.1-17, março 2011.

CORRÊA, Roberto Lobato. O espaço urbano. São Paulo: Ática, 2003.

CORRÊA, Roberto Lobato. "Espaço, um conceitochave da Geografia”. In: CASTRO, Iná Elias; GOMES, Paulo César da Costa; CORRÊA, Roberto Lobato (Orgs.). Geografia: conceitos e temas. Rio De janeiro. Bertrand Brasil, 2007. p.14-47.

DUNCAN, James S. The city as text: the politics of landscape interpretation in the Kandyan kingdom. Cambridge: Cambridge University Press , 1990.

FOUCAULT, Michel. História da sexualidade 1: a vontade de saber. Rio de Janeiro: Graal, 1988.

GRUPO ESPERANÇA. Direito Humanos: Brasil sem transfobia. Curitiba: Grupo Esperança, s/d.

LOURO, Guacira Lopes. Um Corpo Estranho. Ensaios sobre sexualidade e teoria queer. Belo Horizonte: Editora Autêntica, 2004 .

MASSEY, Doreen B. Pelo Espaço: uma nova política da espacialidade, Rio de Janeiro: Bertrand Brasil. 2008.

MOTT, Luiz; CERQUEIRA, Marcelo; ALMEIRA, Cláudio. O Crime Anti-Homossexual no Brasil. Salvador: Editora Grupo Gay da Bahia, 2002.

NAMASTER, Viviane K. "Genderbashing: sexuality, gender and the regulation of public space". In: Namaster, Viviane K. Invisible Lives: The Erasure of Transsexual and Transgendered people. Chicago: University of Chicago Press, 2000. p.135-156.

Organização Mundial da Saúde, World report on violence and health: summary. Geneva, World Health Organization, 2002. Disponível em: $<$ http://www.who.int/violence_injury_prevention/viole nce/world_report/en/summary_en.pdf $>$. Acesso em: 29 março. 2012.

ORNAT, Marcio Jose. Território da Prostituição e a instituição do ser travesti em Ponta Grossa - PR. Dissertação de Mestrado (Mestrado em Gestão do Território). Universidade Estadual de Ponta Grossa, 2008.

PRINS, Baukje; MEIJER, Irene Costera. How Bodies

Vinicius Cabral, J oseli Maria Silva e Marcio J ose Ornat 
Come to Matter: An Interview with Judith Butler. Signs, vol. 23, n 2, p. 275 - 286, 1998.

SANTOS, Milton. Por uma Geografia Nova - Da crítica da Geografia a uma Geografia Crítica. São Paulo: Editora Hucitec, 1986.

SILVA, Joseli Maria. A Verticalização de Guarapuava (PR) e suas Representações Sociais. 2002. Tese (Doutorado em Geografia) - Programa de Pós-Graduação em Geografia, UFRJ, Rio de Janeiro RJ.

SILVA, Joseli Maria. A Cidade dos Corpos Transgressores da Heteronormatividade. In: Silva, SILVA, Joseli Maria (Org.). Geografias Subversivas: discursos sobre espaço, gênero e sexualidade. Ponta Grossa: Editora Toda Palavra, 2009. p.136-149.

SOUZA, Marcelo Lopes de. Algumas notas sobre a importância do espaço para o desenvolvimento social. Revista Território, ano II, No3 jul./dez. 1997. p.13-35.

SOUZA, Marcelo Lopes. Mudar a Cidade: Uma introdução crítica ao Planejamento e Gestão Urbanos. Rio de Janeiro: Bertrand Brasil, 2002.

VALENTINE, Gill. (Hetero)sexing space: lesbian perceptions and experiences of everyday space. Environment and Planning D: Society and Space, v.11, n.4, p.395-413, 1993.

WEINBERG, George. Society and the Healthy Homosexual. New York: St Martin's, 1972. 


\section{estruturado.}

Data

Local da Entrevista:

\section{Identificação da entrevistada}

1 - Nome fictício:

2 - Idade:

3 - Atividade profissional

4 - Atua na atividade de prostituição? Como atividade principal de renda/casual?

5 - Auto-identificação de gênero:

6 -Você participa de alguma instituição politica, como Ong ou Grupo e Direitos humanos?

\section{Experiências de Morte com pessoas de seus convívio como travesti}

- Você tem fotografias de travestis que já faleceram? Pode me mostrar?

- Quantas pessoas aparecem na foto que são travestis? Quantas delas já faleceram?

- Fale sobre cada uma delas que já faleceram

- Você a conhecia bem?

- Como ela era?

- Como ela faleceu? Onde? Que idade?

- Como a família reagiu?

- Como os amigos reagiram?

- Ela recebeu socorro médico?

- Se foi homicídio, quem foi a pessoa?

- A policia puniu os culpados?

- Quantas pessoas travestis que você sabe que já sofreram graves violências, chegando ao risco de morrer? Quem foram? Como foi a violência? Quem foi o/a agressor/a? Como ela foi tratada?

- Quantas pessoas travestis que você viu ou soube da morte? Você consegue dizer a causa morte de cada uma?

\section{Suas expectativas sobre violência e morte}

- Como você avalia a violência na vida de travesti? Fale sobre a frequência, tipos e seus maiores temores?

- Em quais espaços você se acha mais vulnerável à violência e a morte? Há espaços que você evita frequentar por causa do medo de violência contra você?

- Você já sofreu graves violências, chegando ao risco de morrer? Como foi a violência? Quem foi o/a agressor/a? Como foi tratada?

- Qual o tipo de violência que você tem mais medo de sofrer?

- Como você avalia sua vida no futuro? Quais as suas expectativas?

- Você se vê no futuro como uma pessoa idosa?

- Esta se preparando para a sua velhice em termos financeiros, e de saúde?

- Você pensa sobre sua morte?

- Se sim, qual é a sua ideia de morte? Tipo de morte? Local, expectativas em relação à sua fámilia, amigos e a sociedade?

- Como você pensa que as instituições de saúde tratariam casos de violência que poderiam levar à morte?

- Como você imagina que a sociedade pensa sobre a morte de travestis?

Avaliação livre: como você avalia a relação entre a vida e morte de pessoas travestis? 